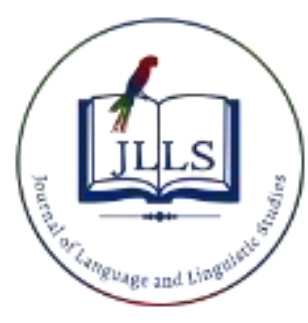

Available online at www.jlls.org

JOURNAL OF LANGUAGE

AND LINGUISTIC STUDIES

ISSN: $1305-578 \mathrm{X}$

Journal of Language and Linguistic Studies, 16(2), 521-536; 2020

\title{
Opinions of EFL students regarding autonomous learning in language teaching
}

\author{
Esmira Mehdiyev a 1 (iD \\ ${ }^{a}$ Sivas Cumhuriyet University, Sivas, Turkey
}

\section{APA Citation:}

Mehdiyev, E.M. (2020). Opinions of EFL students regarding autonomous learning in language teaching. Journal of Language and Linguistic Studies, 16(2), 521-536.

Submission Date:10/10/2019

Acceptance Date:29/03/2020

\begin{abstract}
The purpose of this study is to reveal the opinions of the Sivas Cumhuriyet University students, majoring at English Language Teaching Department in the 2017-2018 academic year, about the autonomous learning process to acquire English speaking proficiency. This study, which aims to reveal the sources that affect the students' autonomous learning activities and speaking skills in English language learning, has been conducted with qualitative study methods and is in descriptive survey model. Interviewing method was chosen as the data collection tool of the study. A semi-structured interview form was prepared and conducted in order to reveal the students' opinions about the language learning process, the activities they do individually in order to improve their English speaking proficiency, the sources affecting their speaking skills, and their recommendations for students who want to improve their speaking skills. Qualitative data were analyzed by descriptive analysis, and the data obtained according to the framework formed were interpreted and supported by direct quotations when necessary. Studies on the effects of autonomous learning activities on development of English speaking competence report that auto autonomous learning activities are: making foreign friends, watching foreign movies and listening to foreign music, playing video games, attending drama courses and situations emerging out of individual and environmental circumstances.
\end{abstract}

(C) 2020 JLLS and the Authors - Published by JLLS.

Keywords: autonomy; autonomous learning; English speaking proficiency

\section{Introduction}

Language teaching methods have been improving as the approaches towards foreign language teaching evolved throughout the history. Teacher-centered traditional education methods have been replaced by student-centered methods that activate students' individual powers and enable students to participate in learning. As Oğuz (2013) states, in a student-centered learning process, students are expected to make their own choices, to take responsibility, to be motivated intrinsically, and to regulate and control their behavior without being dependent on others. The necessity of a student-centered education came to the forefront with the concepts such as goal setting and evaluation were introduced for discussion. Therefore, the question "how should I teach?" has been replaced by the question "how

\footnotetext{
${ }^{1}$ Esmira Mehdiyev. Tel.: +903462191010

E-mail address: emehdiyev@cumhuriyet.edu.tr
} 
does a student learn?" (Aydoğdu, 2009). In other words, this approach, which emphasizes learning rather than teaching, attaches importance to learner autonomy and to the support of the participation of the learner in learning (Wang, 2011). Students' self-learning efforts and motivations began to play an important role in learning. The nature of learning lies in the self-learning of the student and in finding the ways of learning. The constructive behavior of the student in the learning process also affects the permanence of learning.

The constructivist approach, based on the student's autonomous learning in language education, has been subject to many studies and been examined from different perspectives by many researchers (Candy, 1991; Mc.Comb, 1997; Wulff, Hano, Buik, 2001). While explaining the constructivist approach, which is one of the theories of learning psychology and the basis of autonomous learning, Tok (2011) emphasizes that this approach encourages self-directed learning, and that it puts forward a necessary condition for student autonomy.

\subsection{Literature review}

Learner autonomy is a broad field, and has been interpreted by different definitions by researchers working in this field. Learner autonomy is defined as the learner taking the responsibility of their own learning, in a report named "Autonomy and Foreign Language Learning" proposed to the European Council in 1981 by Henry Holec, who was a researcher in the field of adult education, and who conducted studies especially on foreign language learning (Little, 1997; Benson, 2001). Similarly, Dickson (1987) defines autonomy as a situation in which the learner undertakes all the decisions about learning. Nunan (1997) argues that learner autonomy may occur in different situations and states that a fully autonomous learner has the competence to make and implement all decisions. According to Benson and Voller (1997), learner autonomy can be defined as the ability to take responsibility by self or the ability to take self-managed responsibility, and it can be an indicator for predicting academic performance. Stating that autonomy has a multidimensional capacity structure and can take different forms for different individuals, authors also argue that this can take different forms for the same individuals in different contexts and at different times. Holec (1981), Allwright (1990) and Little (1991) define autonomous individuals as individuals who are aware of learning programs, who accept learning responsibilities, who determine learning objectives, who determine learning activities and attempt to carry out these activities, and who are able to evaluate the efficiency of their activities upon reviewing their learning processes.

Demirel and Mirici (2002) stated that the learner autonomy does not mean that all situations of education will totally be under the control of the learner, and that the teacher should carry out the practices that will respond to the wishes and needs of the learner in in-class and non-class activities. Vygotsky (1991) sees learning as a supported performance issue and emphasizes the social interactive dimensions of the learning process. If we explain the role of the teacher according to this model, teachers are responsible for creating an autonomous environment and for sustaining this environment in order for the students to become more autonomous. According to Holec (2011), teachers should always remain close observers of all the pedagogical dimensions of their students. This approach, which suggests that teachers and students take common roles in the autonomous learning model, argues that the teacher is a learning expert and the student is an expert in their own learning. It is believed that both of them can take some risks in this process, but as a result of the continuity of their work, they are still likely to share their satisfaction.

The concept of "Learner Autonomy" can be summed in three descriptions according to the schematic adaptation of Holec (1994):

a) Learners must acquire the ability to take responsibility to learn by themselves, 
b) Learners must acquire sources that enable them to learn by themselves,

c) Teachers must be trained according to their new roles.

According to Aydoğdu (2009), learning is synonymous with the teacher-independent study of the learner. The term "independence" here means that the learner can freely benefit from a pre-determined curriculum. According to Güneş (2012), the individual needs to be able to make his/her own decisions according to his/her own wishes and thoughts and to make his/her own choices on his/her own will, without difficulty, and without being obstructed or being dependent on others. The learner who is successful in this process is a learner who can plan and evaluate self-development. The ability of the individual to plan the learning process, to determine the objectives of this plan, to achieve the objectives determined by this plan, and finally to follow and manage the whole learning process constitute the basic skills of autonomous learning. Demirtaş (2010) argues that a student with these skills can direct and manage the learning process from start to finish.

Recent developments in educational technology, internet and virtual learning environments provide an effective basis for the application of modern approaches such as the learning autonomy in the fields of foreign language learning and teaching. The autonomous individual who learns language on this basis can freely choose the information to be learned and effectively take responsibility in learning. In this context, Can (2012) argues that opportunities offered by the virtual reality platform named "Second Life" in order to support learner autonomy in the foreign language learning process provides the freedom of choice for students, providing them the opportunities to design, create, and produce the learning environment, and it leads students to create learning process and to adopt the process and the environment. In the context of foreign language learning, the SL platform promotes autonomous learning by enabling students to communicate and interact among each other, with other people, with learning materials that they have created, and with objects.

\subsection{Research questions}

In the literature, it is stated that autonomous learning is effective in learning foreign languages. It is seen that mentioned studies on this subject are studies on the general language proficiency. With this study, it is expected that autonomous learning will contribute to the deficiency in literature in terms of revealing the process of gaining English speaking proficiency. At the same time, it is foreseen that it will shed light on the autonomous learning activities and suggestions for speaking foreign languages. The purpose of this study is to reveal the opinions of the Sivas Cumhuriyet University students in the 2017-2018 academic year about the autonomous learning process to acquire English speaking proficiency. The following questions were sought within the framework of this general purpose.

1. What are your opinions on the language learning process of English speaking proficiency?

2. Can you tell us some of the activities you do in order to improve your English speaking skills?

3. What are your recommendations for students who want to improve their speaking skills?

\section{Method}

\subsection{Study pattern}

This study, which aims to reveal the sources that affect the students' autonomous learning activities and speaking skills in English language learning, has been conducted with qualitative study methods and is in descriptive survey model. In qualitative studies, data collection and analysis, theory development and correction, selection of study questions and re-focusing on questions, determination 
of validity threats and dealing with them are developing more or less simultaneously, influencing one another. The phenomenology pattern, which should be carefully designed at each stage, should be based on sound reasons and is considered one of the study methods requiring knowledge of technical study, determined the approach of the study. This choice was influenced by the fact that the study included students who had significantly improved their speaking skills in the classroom setting.

\subsection{Study group}

The study group was determined by the criterion sampling method, highly preferred in qualitative studies. The achievement score (100-85) of the students in the oral communication skills course was taken as criterion. Based on this criterion, the study group was determined in accordance with the consensus of the lecturer responsible for the course and a faculty member from the Department of English Language Education, who stated that the students' speaking proficiency was at an advanced level compared to the average of their respective grades. In the 2017-2018 academic year, 8 students from the Foreign Languages Teaching Department of the Faculty of Education of Sivas Cumhuriyet University and 8 students from the Preparatory School participated in the study. Demographic data of the participants in the study group are shown in Table 1.

Table 1. Demographic data of the participants

\begin{tabular}{|c|c|c|c|c|c|}
\hline $\begin{array}{l}\text { Participant } \\
\text { Name }\end{array}$ & Age & Birthplace & Educational Status of Parents & $\begin{array}{c}\text { Place of } \\
\text { Education }\end{array}$ & Gender \\
\hline $\mathrm{S} 1$ & 32 & Sivas/Zara & College & Province & Female \\
\hline S2 & 18 & Sivas & University & Province & Female \\
\hline S3 & 19 & Sivas & University & Province & Female \\
\hline S4 & 21 & Giresun & College & Province & Male \\
\hline S5 & 20 & Denmark & $\begin{array}{l}\text { Middle School- Elementary } \\
\text { School }\end{array}$ & Abroad & Female \\
\hline S6 & 18 & Sivas & $\begin{array}{l}\text { High School- Elementary } \\
\text { School }\end{array}$ & Province & Male \\
\hline S7 & 19 & Kayseri & High School & District & Female \\
\hline S8 & 23 & Muğla/Dalaman & High School & District & Male \\
\hline S9 & 18 & Dagestan & College & Province & Male \\
\hline S10 & 18 & Nevşehir & $\begin{array}{l}\text { Elementary School- High } \\
\text { School }\end{array}$ & Province & Male \\
\hline S11 & 20 & Sivas & University-High School & District & Female \\
\hline S12 & 19 & Lüleburgaz & Middle School & District & Female \\
\hline S13 & 19 & İzmir/Ödemiş & Elementary School & Province & Male \\
\hline S14 & 19 & Antalya & College & Province & Male \\
\hline $\mathrm{S} 15$ & 28 & Sivas & High School- Middle School & District & Male \\
\hline S16 & 18 & Ankara & Middle School & District & Male \\
\hline
\end{tabular}

As shown in Table 1, 9 of the participants were male. Upon looking at the place where they received their education for the longest period, it is seen that 6 of the male students received education in provincial schools and 3 of them in district schools. 7 of the participants were female students. 3 of these students received education in provincial schools, 3 of them in district schools, and 1 of them abroad. Upon examining the educational level of the parents of the students, it is seen that the parents of 9 participants were primary school, middle school, or high school graduates and 7 of them were college or university graduates. The students in the study group were coded as S1 - S16 according to the number of participants. 


\subsection{Data collection tool}

Interviewing method was chosen as the data collection tool for the study. According to Patton (1987), "Interviewing form method is prepared in order to receive the same type of information from different individuals by gravitating them towards similar subjects. The interviewer working with this method, developed to guarantee the scope of all dimensions and questions related to the study problem, may change the sentence structure or the order of the questions during the interview, may dive into the details of some subjects or may adopt a more conversational method (cited in, Yıldırım and Şimşek, 2005). Upon scanning the literature and investigating the studies on the subject, a semi-structured interview form was prepared in order to reveal the students' opinions about the language learning process, the activities they do individually in order to improve their English speaking proficiency, the sources affecting their speaking skills, and their recommendations for students who want to improve their speaking skills. Two experts in the field of English teaching and two faculty members in the field of educational sciences were interviewed and their opinions about the interview form were taken into consideration. In addition, the interview form was piloted on three students who were not included in the study group in order to test the comprehensibility of the questions in the semi-structured interview form. The semi-structured interview form was completed in accordance with the opinions of the experts and the faculty members and the opinions acquired from the pre-application. The participants were informed about the importance, purpose and content of the study by the researchers. The interviews were recorded by the researchers upon receiving permission of the participants, and the statements of the participants were later converted into written text.

\subsection{Data Analysis}

Qualitative data were analyzed by descriptive analysis. Wolcott's (1994) approach to data analysis is based on presenting the collected data as faithfully as possible to the original form and, when necessary, presenting it to the reader by quoting directly from what individuals say, and is very similar to the "descriptive analysis" approach known in the literature (Miles \&Huberman 1994; Weitzman, 2000). The researcher, following the four stages proposed in descriptive data analysis, primarily formed a framework for data analysis based on the dimensions included in the interview. Then, the data obtained according to the framework formed were interpreted and supported by direct quotations when necessary. The causational explanations and the comparison between different facts in the interpretation of the findings were carefully performed.

\subsection{Credibility and transferability}

Instead of the concepts of validity and reliability, the concepts of credibility, transferability and consistency proposed by Roberts and Priest (2006) for qualitative studies were chosen in this study. Before the interview, participants were informed about the purpose, content and the degree of expertise of the interviewing researcher in their respective fields, in order to provide credibility. Upon ensuring that the recording device worked, the questions were asked carefully in order to ensure that the interviewee would react in a relaxed, honest, and direct manner. The researchers tried to provide objectivity by transcribing the recorded statements within the scope of the subject and by obtaining confirmation from the participants about their opinions. Each stage of the study was described comprehensively and explicitly in the description of the work to ensure transferability. In addition, the recording transcriptions containing the participants' opinions and the encodings of the participants are kept to be examined if necessary. In order to provide consistency, the harmonization of the framework created by the researchers was provided in order to ensure consistency. Common values were obtained 
by the researchers upon explaining, correlating, and interpreting the findings acquired during the application of descriptive analysis method chosen for data analysis.

\section{Results}

In this section, the opinions of the students in the study group, who are in the preparatory and first grades of the university, about the language learning process, about the acquisition of speaking proficiency, the autonomous learning activities in English language learning, the factors affecting their speaking skills, and the recommendations for students who want to improve their speaking skills, are explained.

\subsection{Student opinions on language learning process about the acquisition of English speaking proficiency}

According to the student opinions, the speaking skills acquisition in the process of English language learning were based on different sources varying by individual, and these sources were identified as using technology, socializing, interest in reading books or listening to music, watching movies or series, regarding teachers as role models, and establishing friendships.

\subsubsection{Student opinions on English learning as a tool for using technology}

The statement by S15 as "We started to get to know computers at early ages and we tried to learn it because the programming language was in English" shows that English is a necessary communication tool for using technology. The statement by S11 as "We started to talk in the classroom but these conversations were limited and in Q\&A format. Having thought that these would not help me improve my speaking skills, I started to meet people online," reveals the importance of technology in English language learning. S9 conveyed the idea that online video games contributed to English speaking as a helping tool by stating "We would try to communicate with foreigners in online games". The statement by S10 as "We would play online games not to play but to practice speaking. I was able to speak as I was a 7th or 8th grader but I needed practicing. Therefore, I played games consciously," shows that online games that young people play in spare times being in English can be for the benefit of them. Using computers, following current events through computers, and widespread use of computer technologies in a wide range of life, make learning English a necessity. Technological knowledge can be used in a more qualified way matching up with English knowledge. It is clear that the need to use technology more effectively affects the need for language learning.

\subsubsection{Student opinions on English learning as a tool for socializing}

S14 stated "Two older sisters of mine were English Language and Literature students. They would talk in English with each other and I eagerly started to learn English from 4th grade onwards. Thus, I became more and more interested in learning English". The statement by S1 as "My cousin received education in a university that provided $100 \%$ foreign language education. We would always talk in English when we were together. He had some foreign friends and we would also talk with them to practice" reveals the social interaction side of the language learning process.

\subsubsection{Student opinions on the effects of the interest in reading books and listening to music on English language learning}

The statement by S6 as "I started to understand English by listening to music, I started to listen thrash metal, then moved to Pro. You can improve your speaking by listening to music" reveals the positive effect of listening to music on language learning. S9 stated that language learning was an autonomous learning process and explained that individuals had to wonder and to be interested in order to learn by 
stating "I am very interested in fantastic stories. There were not many fantastic stories in Turkish, I had to read and understand stories in English. And I learned English by deducing the meaning from figurative expressions and by wondering what the words or word groups meant." One of the participants that believed reading books have a great contribution in language learning, S1 stated his opinions as follows: "I would read books in English loudly to myself and I enjoyed listening to myself while learning English. The year after, my English teacher told everyone to stand up and introduce themselves in the first class of high school. When it came to me, I stood up and started speaking fluently. I had never realized until that moment that I can talk because I hadn't had practice except reading books to myself."

\subsubsection{Student opinions on the role of the teacher in English learning}

Statements by S13 as "My teacher made me love English. Watching TV series also sounded nice," and by S12 as "After I got acquainted with my English teacher and after he motivated me, I started to be interested in English, and then I passed English exams by 90 at least," shows that the role of the teacher is crucial in language learning process. The existence of teachers as role models can be seen as an important source of influence. It is seen that English language learning affects the cognitive and emotional behaviors of the students via social learning. Teachers appeal to the cognitive fields of students with their field competence and to emotional fields with their care and compassion. S11 explained how she regards her teacher as a role model: "I had an exceptional teacher in 6th grade. My teacher was a model for me then and had a great impact on my language level I reached." S1 described her teacher's effect on her English learning as follows: "One day, English teacher told us to introduce ourselves. I saw that, when I introduced myself to the class, I expressed myself better than my friends did. I gained confidence after I listened to myself speaking. I saw I could do that and I liked that everybody around me realized that. This encouraged me to learn more."

\subsubsection{Student opinions on the role of establishing friendships and maintaining them on English learning}

S5 talked about her experiences while living in Denmark and emphasized the important effect of speaking English with her friends on learning the language and improving her speaking skills: "We would talk to each other in English as all of us had a decent level of English speaking. We would not even force it, we just liked talking English in our daily life." S11 told that she believed that the language is learned by speaking and stated "We would talk in the classroom but these conversations were limited and in Q\&A form. I thought that this practice would not be enough for me to improve my speaking, so I started to meet people on the Internet. I was a 2 nd grader in high school at the time. I tried to improve my English by making foreign friends on the Internet and by video-chatting with them."

\subsection{Autonomous learning activities of students in the acquisition of English speaking proficiency in language learning process}

Students stated their autonomous learning activities as making foreign friends, watching foreign movies and listening to foreign music, playing video games, drama course, and situations emerging out of individual and environmental circumstances.

The statement by S16 as "I improved my vocabulary and learned grammar by messaging with foreign friends" shows that talking with natives is done as an autonomous learning activity. The statement by S11 as "I started to meet people online, and writing to people online and video-chatting with them improved my English and helped me gain self-confidence," shows that establishing friendships with foreigners helps to improve language learning. It can be stated that establishing friendship enables interaction and learning by experiencing.

Watching foreign movies/series is another autonomous learning activity in English language learning. The statements by S15 as "I watched a movie with Turkish subtitles and later tried to understand it without subtitles," and by S10 as "I was trying to guess what the words meant by the events 
that were happening in the movie," are related to trying to understand a foreign movie without the help of subtitles or dubbing. On the other hand, the statement by S7 as "Watching movies with subtitles helped me improve my vocabulary and pronunciation," shows that watching movies is effective in improving language skills. The statement by S2 as "Watching TV series helped me improve my speaking skills" shows that watching TV series can be considered as an activity to improve English speaking skills. These statements can be interpreted as watching movies/TV series have a role in improving listening and speaking skills.

The statements by S13 as "Listening music helped me learn some words and certain patterns" and by S2 as "I searched for a musical style for myself and I started to listen to metal music. After a certain point, I started to understand the songs automatically. I started to imitate the songs and find myself talking to myself," imply that listening to music improves skills to understand and speak in language learning. The statement by S1 as "I would listen to music that I liked and would write their lyrics, then would try to learn the songs by listening repeatedly," is an example to show that interest in foreign music contributes to language learning. These statements can be interpreted as singing along when listening to music contributes to latent learning and memorizing songs is effective in learning words and some sentence groups.

Playing video games in English is among the autonomous learning activities. The statements by S15 as "I would write to others with the automatic dialogue option in an online game" and by S14 as "I would speak with foreigners with microphone and headphones in an online game and even learned different accents," emphasize the necessity to communicate to play games, thus, to speak English. Besides, the statement by S2 as "I started to speak English from early ages while playing online games, even when I had little knowledge," shows that playing games can affect language learning even at early ages. It can be said that playing video games is an autonomous learning activity since it requires speaking and writing English.

The statement by S9 as "I went to drama course for 2 years and applied what I learned there in language learning. I would practice sentences until my diction, fluency, pronunciation, body language, and gestures were perfect, and I would study interesting texts," can be shown as a practicing technique, applying what one learns in drama course to English practicing. Drama activity can be interpreted as experiencing and feeling a language, rather than just speaking, writing, listening, or understanding.

The statement by S12 as "I am a talkative person. I improved my speaking skills naturally and casually in my own right" shows that being talkative can contribute to English learning as the individual use this trait to create an autonomous learning activity. As for autonomous activities related to environmental characteristics, the statements by S9 as "I was exposed to three different languages until 1st grade (Azerbaijani, Russian, Turkish). I learned these languages by ear and I think this facilitated my English learning," and by S8 as "I started to work in the tourism sector. I improved my English and learned different accents through communicating with tourists in the business," shows that these activities can be considered as autonomous activities that enable self-learning through exposure.

While talking about the individual activities to improve speaking skills, S4 stated "Talking to yourself. People can call you mad, especially if you are alone, but doing this improved my English speaking. Besides, it gets imprinted on the mind since the dialogues in movies are in vulgar language and even if you don't use it actively, you gain the ability to talk to some degree," and S2 stated "I would impersonate a character that I like as a hobby". As a similar activity, S1 stated "I would read them out. I took pleasure listening to myself while learning English," and S3 stated "You don't even talk to somebody. For example, you find a news text and read it out, and then you look up how a native speaker pronounces it. You compare your pronunciation with theirs". Either consciously or for fun, the activity 
of "talking to oneself" can be considered as an effective individual activity in fluent English speaking and proper pronunciation.

You should provide sufficient detail to allow the work to be replicated. Methods already published should be indicated by a reference. Only relevant modifications should be described here.

\subsection{Recommendations for learners on autonomous learning}

As for autonomous activities in language learning, students recommended activities such as showing courage to speak English/practicing, and developing entertaining hobbies such as watching movies, listening to music, keeping a diary etc.

Regarding showing courage to speak English/practicing, S16 stated his opinion as "A language can only be learned naturally. The learner must be courageous". Similarly, S14 emphasized on the necessity of speaking in language learning by stating "A language is learned naturally, by speaking without hesitation and linguistic forms get imprinted on one's mind". S11 stated that she believes it is important to be courageous and to not hesitate to speak English and that a language is learned by speaking. S1 stated that "the individual should believe that he/she can do it and should activate the four skills in individual practices". S7 and S10 recommended those who want to speak fluently to practice heavily, and S6 recommended repeating the learned patterns and sparing time to listen. The notion that constant speaking and practicing is effective in English learning is compatible with the statement by S13 as "One should stay in a place where English is spoken to learn English and should live there in order to reinforce what is learned". S2 recommended 'integrating English into life style and reanalyzing the experienced events in English'. These can be activities alternative to living in an English-speaking place. In this respect, engaging in the language learned is considered an effective learning activity in ensuring permanency in language learning.

Students also recommended developing entertaining hobbies, such as watching movies, listening to music, or developing another hobby as an autonomous activity in language learning. S15 stated that "watching movies without subtitles and writing down what is listened can contribute to learning" and S12 stated that "listening to songs or watching movies help learning new words and correct pronunciation". S10 and S8 stated that watching movies with subtitles is a must and S10 added that "listening to songs can improve vocabulary". S9 recommended writing movie scripts intended for areas of interest and stated that this activity can contribute to permanency as it requires use of multiple words and sentences. S5 agreed that entertaining and willing learning is effective and stated that "learners should not read long articles in order to not get bored". Similarly, S4 stated that the crucial thing is to love what you do and to integrate liked activities into language learning. For instance, S3 recommended learners to engage with comical content, forums, and news using the Internet. Therefore, they can learn the uses of both official and daily language. S1 stated that "keeping a diary can be an individual activity. Students presented recommendations centered around the idea that doing liked individual activities (listening to music, watching movies, writing scripts, keeping a diary, etc.) in English can be effective in English learning and that different activities can be done to reinforce different skill fields (speaking, writing, listening, understanding). It can be stated that developing hobbies provide entertaining learning.

Describe the sample or participants who participated in your study and the setting when relevant. In most studies, your participants are likely to be people, but a sample can comprise of a group of cases or items. You should present information related to the sample, such as how the sample was selected, the size of the sample, and relevant demographic characteristics about the sample. You, as the researcherauthor, have to decide which demographic characteristics are relevant to your study. For example, GPA, age, or IQ scores of the study's participants may be considered important demographic characteristics in one study, but not in another. Understandably, the exact information about the sample in your study 
(e.g., the mean age or the number of males and females in each group) should provide a general description of the study's participants.

\section{Discussion}

In this section, the results with regard to the opinions of university students on the autonomous learning process to acquire English speaking proficiency are discussed and some suggestions are made.

When the student opinions about the autonomous language learning process in English are examined, It was revealed that students stated the themes such as using technology, interest in music or watching film or TV series, reading books, establishing and maintaining friendships (socializing tool/practicing), and the influence of teachers as common opinions. For autonomous learning activities, the use of an intermediary variable such as technology seems to be driving force. The finding of using technology in the language learning process in acquiring English speaking proficiency coincides with the finding of the study by Farivar and Rahimi (2015) and with the strong relationship between technology and autonomous learning. In this context, it can be stated that the use of technology in foreign language autonomous learning has an important role. Benson (2011) emphasized that the technology based approach as one of the autonomous learning activities in foreign language learning in daily life has a facilitating effect on foreign language learning. Rüschoff and Ritter (2010) concluded in their study that the use of technology was a tool for learning foreign languages. It is seen that the use of technology in the autonomous learning process in the English language learning, which is the finding of this study, supports the literature. According to Perren (2010), autonomous learning is closely associated with concepts such as self-regulation, decision-making, personal development, and independent learning. The relevant situation facilitates autonomous learning by creating intrinsic motivation in individuals. In particular, technology can help achieving a meaningful learning content by increasing the quality of instructional activities. Çoşkun and Marlowe (2015) point out the importance of technological tools in learning English and draw attention to the fact that children are now born into this reality. Thus, each learner creates an autonomous environment for him/herself. Another theme in the English language learning process is students' interest in listening to foreign music and watching foreign movies. Activities such as listening to music and watching movies or TV series can be regarded as intrinsic motivational sources that meet the interests and needs of students. The results of the study indicate that the intrinsic motivational sources that trigger this process vary according to the needs of individuals to acquire foreign language. According to the participants, the motivational sources in English language learning are socializing, interest in music, using technology, watching movies or TV series, seeing teachers as role models, and establishing and maintaining friendships. In this context, it is consistent with the opinions of the researchers who argue that autonomous learning is not an individual quality and is influenced by internal and external conditions (Paiva,2005; Tok, 2011). According to Chan (2016), learners' autonomous learning is at the center of learning a second language in lifelong and learnercentered learning. As part of the popular culture, online networks have a crucial role in the learning of learners. In these study findings, it is seen that foreign music and foreign TV series enable opportunities for learners in learning autonomous language. Most of the learners have increased their language learning proficiencies through movies, songs and TV channels. It is also seen in another theme of the study, the influence of teachers, that the learners need the guidance of their teachers and they consider them as role models. Hafner and Miller (2011) argue that learner autonomy can be improved with the creation of an environment in which learners can be guided by curriculums structured by teachers. The improvement of autonomous language learning proficiency through friendships is seen as an important focus in another finding of the study. According to Ergur (2010), the prerequisite for success in foreign language education in the acquisition of learner autonomy is the integration of learner autonomy into 
the learning-teaching process. The teacher should be equipped to teach and the student to be self-aware and they should cooperate during the learning-teaching process for the improvement of autonomous learning process. It can be realized if teacher trainers reflect a pedagogical structure, which enhances the autonomy of the learner and the instructor on the teaching process, and successfully implement their roles as a person who manages the process of learning-teaching, is resourceful and consulting as well as a person who transmits the information. Hamada (2012) states that a social media tool such as Facebook has an important role as a means for learners to connect to the world in learning a language. It can be said that Facebook is used as an interaction tool between learners and helps language learning through the establishment of close relationships. Maynard and Perakyla (2006) and Hymes (2005) indicate a strong relationship between social interaction and language. In addition, Edwards (2006) points out that the effectiveness of social interaction plays a role in language learning. The empirical results in the literature are similar with the findings of this study. Therefore, it can be shown that it is effective in learning autonomous language as a means of socializing in English speaking proficiency.

The study findings on the autonomous learning activities of students in obtaining English speaking competence in the process of language learning indicate that autonomous learning activities are: making foreign friends, watching foreign movies and listening to foreign music, playing video games, drama course, and situations emerging out of individual and environmental circumstances. Sert (2007) draws attention in his study to the fact that learners are generally prepared to enter the autonomous learning process, but are not confident enough to feel sufficient to learn by themselves and to use the media and the Internet in their personal language improvement. This can be regarded as an indication that learners hesitate to learn autonomously. For example, a learner's hesitation in making a foreign friend may mean that he/she ignores an important activity in the language learning process. The opinion expressed by Sert (2007) points out that the activity of interaction by the learners in this study with foreigners has an important role in autonomous learning. The hesitation for the use of media and the Internet in language learning shows that individuals do not have the courage to attempt these activities. Can (2012) points out that the learning opportunities need to be changed by diversifying and expanding learner autonomy on the basis of Internet and virtual learning environments. In addition, the information boom, which is supported by learning networks such as the Internet and virtual learning environments, multiplies and diversifies the information that the students need to learn. These require students to make choices and take responsibility as autonomous individuals for information to be learned. Looking at the findings of this study, it is seen that making foreign friends has an important role on autonomous learning. The learners stated that their willingness to learn language increased as a result of the communication process established with foreigners on the internet or in different ways. Learning through friendships provides serious opportunities for autonomous learning by creating interactive language environments. Similarly, watching foreign movies and listening to foreign music has also been shown to improve learners' language learning skills. For instance, a student said that his English vocabulary has improved upon repeating and memorizing English songs by imitating them. This example emphasizes the importance of listening activity in autonomous learning.

One of the basic autonomous learning tools we encounter in the study results is video games. The English infrastructure of video games increases the interest and attention towards the English language. According to Peterson (2010), video games now function as learning tools and language teaching is one of them. Autonomous learning through video games can contribute to language learning. Can and Turkmen (2017) point out that video games facilitate learning in language teaching. It is emphasized that video games have an important role in attraction to and motivation for language learning.

Another result is related with that the drama skills play an important role in language learning. Because drama skills increase self-confidence, enable tending towards speaking without being selective and without worrying. English learners point out that courage and assertiveness play a crucial part in 
language learning. In the results of the study, it is seen that the participants emphasize that one can overcome language learning by being courageous and assertive. Soyer (2016) points out that the use of creative drama in language learning activities has yielded significant learning outcomes. Şimşek (2016) draws attention to the finding that drama technique provides strong memorization of English vocabulary. These study results show that drama-based language learning activities increase permanency in language learning and contribute significantly to learning.

At the same time, the effect of environmental factors on language learning strengthens autonomous language learning. Spending time in environments where different languages are spoken provides important contributions to language improvement. This is defined as exposure in the literature. Exposure to a new language positively affects also the willingness to learn language. According to Özer and Korkmaz (2016), it is stated that if the students' environment can be equipped with a positive way of life for learning the language, learning foreign language will also be affected positively. According to Yalçın (2014), social learning, which is student-oriented and is performed with cooperation, is similar to the factors that a child experiences during learning his/her native language. The child interacts and communicates with his mother first. When he grows up, he starts to develop his native language by communicating with other people around him. At this point, the social environment and social relations of the child are important factors in terms of language learning and improving. For this reason, mutual interaction and cooperation play an important role in learning a language. Therefore, an individual learning a language needs a motivating instructor and friends with whom he can work and exchange information. All these factors have a positive and reinforcing effect on language learning.

Recommendations on autonomous methods for those who want to learn a language are stated as showing courage to speak English/practicing, developing entertaining hobbies such as watching movies, listening to music, keeping a diary. As an important factor, courage helps learning and speaking a language, which is one of the most important aspects of autonomy. According to Woodhouse (2011), encouraging learners is an important characteristic of teachers in learning and teaching. Morale courage, more than physical courage, helps students to progress their learning process. Courage to learn begins with overcoming fear. This opinion can open the door for the beginning of a pleasant and entertaining learning. Courage can be considered as an important initiator variable in many activities related to language learning. In this context, teachers' attitudes and behaviors that will help students learn a language will facilitate also the work of the learners. According to Seijt, Gandz, Byrne and Crossan (2015), the unique character traits of the leaders, such as courage, play an important role in success. In this context, it will make teachers' work easier if they encourage learners in language learning. According to Barker (2014), the quality of learning influence learners as a result of the eagerness and enthusiasm of teachers. Therefore, in order to support the learning autonomy of learners, the teachers can encourage learners to have more fun while learning. In this study, it is meaningful that the students emphasize courage and entertaining learning. According to $\mathrm{Wu}$, Chan and Haunglera (2014), language learning becomes a disadvantage for learners when they cannot find a real learning environment.

\section{Conclusions}

Following suggestions can be made in line with the results of the study.

English teachers can be asked to tell their students to follow a TV series or a movie as a course activity and to listen to their comments in classroom environment as a Q\&A activity.

English teachers can be expected to encourage their students to speak English during class and to improve their social communication. 
Teachers can also be expected to create circumstances where students can have success by small steps in order to encourage them. In this respect, it can be suitable for language teachers to have educational trainings.

In addition, the students can be told to do homework at certain intervals, which includes recording their conversation in English with a foreigner.

\section{Ethics Committee Approval}

The author(s) confirm(s) that the study does not need ethics committee approval according to the research integrity rules in their country (Date of Confirmation: April 02, 2020).

\section{References}

Aliponga,J., Johnston, C., Koshiyama, Y., Ries, T., \& Rush, T. (2013). Learner autonomy in east Asian university contexts. Journal of Educationaland Social Research MCSER Publishing, Rome-Italy, 3 (7), 83-89.

Allwright, D. (1990). Autonomy in language pedagogy in CRILE Working Paper 6. Centre for Research in Education: University of Lancaster.

Aydoğlu, C. (2009). Yabancı dil öğretiminde otonom öğrenme: Neden ve nasıl? Uluslararası Sosyal Araştırmalar Dergisi, 2(8). 68-74.

Barker, D.G. (2014). Success: From failure to failure with enthusiasm. Studies in Second Language Learning and Teaching, 4(2), 301-325.

Benson, P. (2001). Teaching and researching autonomy in language learning. London, UK: Longman

Benson, P. (2011). Language learning and teaching beyond the classroom: An introduction to the field. In beyond the language classroom (pp.7-16). Palgrave Macmillan UK.

Can, T. (2012). Yabancı dil öğretimi bağlamında öğrenen özerkliğinin sanal öğrenme ortamları yoluyla desteklenmesi. Hasan Ali Yücel Eğitim Fakültesi Dergisi, 17(1), 46-53.

Can, M.Z., \& Turkmen, B. (2017). Bilgisayar oyunlarının yabancı dil eğitimine katkısının araştırılması: ana dili türkçe olan 100 yüksek öğretim öğrencisi üzerinde yapılan araştırma örneği. Tarih Okulu Dergisi (TOD), 10(31), 399-435.

Candy, P. (1991). Self direction for life-long learning. San Francisco: Jossey- Bass.

Chan, H.W. (2016). Popular culture, English out-of-class activities, and learner autonomy among highly proficient secondary students in Hong kong. Universal Journal of Educational Research, 4(8), 19181923.

Çoşkun, A., \& Marlowe, Z. (2015). Technology in elt: english teachers investigate animoto and fotobabble. International Journal of HigherEducation,4(3), 119-128.

Dickinson, L. (1987). Self-instruction in language learning, Cambridge University Press.

Ergür, D.O. (2010). Öğrenen özerkliğinin kazandırılmasında öğretmenin rolü. International Conference on New Trends in Education and Their Implications, Iconte, 11-13 November, 2010, Antalya, 354359. 
Farivar, A., \& Rahimi, A. (2015). The 1mpact of call on iranian efl learners' autonomy, Procedia-Social and Behavioral Sciences, 192, $644-649$.

Seijt, G., Gandz, J., Byrne, A., \& Crossan, M. (2015). Learnıng from boardroom perspectıves on leader character. Ivey Business Journal, January/February, 1 12.http://eds.b.ebscohost.com/eds/pdfviewer/pdfviewer?

Holec, H. (1979). Autonomy and foreign language learning. Strasbourg: Council of Europe.

Holec,H (2011). Training teachers to cope with the inherent variability of their Office. Innovation in Language Learning and Teaching, 5(2), 111-118.

Demirel, Ö. (2003). Yabancı dil ögretimi. İstanbul: Pegem Yayıncılık.

Demirel, Ö.,\& Mirici, İ. H. (2002). Yabancı dil eğitiminde öğrenen özerkliği. Milli Eğitim Dergisi, 155156,76-88.

Demirtaş, İ. (2010). Üniversite İngilizce hazırlı eğitiminde özerk ögrenme becerileri (Unpublished MA thesis). Ankara Üniversitesi, Ankara.

Demirtaş, I.., \& Sert, N. (2010). English education at university level: Who is at the centre of the learnıng process? Novitas-Royal (Research On Youth and Language), 4(2), 159- 172.

Edwards, D. (2006). Discourse, cognition and social practices: The rich surface of language and social interaction. Discourse Studies, 1, 41-49.

Hafner, C. A., \& Miller, L. (2011). Fostering learner autonomy in English for Science: A collaborative digital video project in a technological learning environment. Language Learning \&Technology, 15(3), 68-86.

Hamada, M. (2012). A Facebook project for Japanese university students: does it really enhance student interaction, learner autonomy, and English abilities? In L. Bradley \& S. Thouësny (Eds.), In L. Bradley \& S. Thouësny (Eds.), CALL: Using, learning, knowing, EUROCALL Conference Proceedings (104-110). Gothenburg, Sweden, 22-25 August 2012.

Ivanovska, B. (2015). Learner autonomy in foreign language education and in cultural context. Procedia-Social and Behavioral Sciences, 180, 352-356.

Hymes, D. (2005). Models of the interaction of language and social life: toward a descriptive theory. Inter cultural discourse and communication: The essential readings, 4 -16. Context. Procedia - Social and Behavioral Sciences 180, 352 - 356.

Little, D. (1991). Learner Autonomy1: Definitions, Issuesand Problems. Dublin: Authentik.

Little, D. (1997). Language awareness and the autonomous language learner. Language Awareness, 6(23), 93-104.

Little, D. (2016). The European Language Portfolio: time for a fresh start? International Online Journalof Education and Teaching (IOJET), 3(3), 162-172.

Maynard, D. W., \& Peräkylä, A. (2006). Language and social interaction. In Handbook of socialpsychology (pp. 233-257). Springer, Boston, MA.

Miles, M.B, \& Huberman, A.M. (1994). Qualitative data analysis. Thousand Oaks, CA; Sage.

McCombs, B. (1997). Understanding the keys to motivate to learn (Unpublished doctoral dissertation) George Washington University, Washington 
Nunan, D. (1997). Designing and Adapting Materials to Encourage Learner Autonomy. In P. Benson, \& P. Voller (Eds.). Autonomy and Independence in Language Learning (pp. 192-203). London: Longman.

Oğuz, A. (2013). Öğretmenlerin öğrenen özerkliğinin desteklenmesine ilişkin görüşleri. International Journal of Human Sciences, 10(1), 1273-1297.

Özer, B., \& Korkmaz, C. (2016). Yabancı dil öğretiminde öğrenci başarısını etkileyen unsurlar. EKEV akademi dergisi, 20 (67), 59-84.

Sert, N. (2007). Öğrenen özerkliğine ilişkin bir ön çalışma. İlköğretim Online, 6(1), 180-196.

Soyer, S. (2016). Yabancı dil öğretim yöntemi olarak yaratıcı drama ve etkileri. International Journal of Contemporary Educational Studies, 2(1), 157-163.

Şimşek, H. (2016). Drama yoluyla ingilizce kelime öğretimi: gölbaşı MYO örneği. International Journal of Social Science, 44, 421-430.

Patton, M, Q. (1987). How to use qualitative methods in evaluation. Newbury Park, CA; Sage.

Perren, J.M. (2010). Internet supplements for English vocabulary and reading development to empower autonomous international students. The International Journal of Technology, Knowledge and Society, 6(6),66-84.

Peterson, M., (2010). Massively multiplayer online role-playing games (MMORPGs) as arenas for second language learning. Computer Assisted Language Learning, 23(5), 429-439.

Paiva, V. (2005). Autonomy and complexity, autonomy in second in language acquisition, 146. Retrieved on October, 3, 2009. from http://www.veramenezes.Com/autoplex.htm

Roberts, P., \& Priest, H. (2006). Reliability and validity in research. Nursing Standard, 20, 41-45.

Rüschoff, B., \& Ritter, M. (2001). Technology-enhanced language learning: construction of knowledge and template-based learning in the foreign language classroom, ComputerAssisted Language Learning, 14(3-4), 219-232

Tok, H. (2011). Otonom öğrenme. Elektronik Sosyal Bilimler Dergisi, 10(36), 54-64.

Tok, H., \& Arıbaş, S. (2008). Avrupa birliğine uyum sürecinde yabancı dil öğretimi. İnönü Üniversitesi Eğitim Fakültesi Dergisi, 9(15), 205-227.

Vygotsky, L. (1991). Thoughtand Language. Cambridge, Mass: MIT Press.

Wang, P. (2011). Constructivism and learner autonomy in foreign language teaching and learning: to what extent does theory inform practice? Theory and Practice in Language Studies, 1(3), 273-277.

Weitzman, E. A. (2000). Handbook of qualitative reseach (2nd.ed). Thousand Oaks, CA; Sage.

Woodhouse, H. (2011). Learning for life: The people's free university and the civil commons. Issues in Social Justice, 5(1), 77-90.

Wu, C.J., Chan, G.D., \& Haung, C.W. (2014). Using digital board games for genuine communication in EFL classrooms. Educational Technology Research and Development, 62, 209-226.

Wulff, S., Hanor, J., \& Buik, R-J. (2000). The roles and interrelationships of presence, reflection, and self-directed learning in effective World Wide Web based pedagogy. In R. A. Cole (Eds.), Issues in Web-based pedagogy: A critical primer (pp. 161-181). Westport, CT: Greenwood Pres. 
Yıldırım, A., \& Şimşek, H. (2005). Sosyal bilimlerde nitel araştırma yöntemleri. Ankara: SeçkinYayıncılık.

\section{Dil öğreniminde otonom öğrenmeye ilişkin öğrenci görüşleri}

\section{Öz}

Bu çalışmanın amacı, 2017-2018 eğitim öğretim yılında Sivas Cumhuriyet Üniversitesi, İngilizce Öğretmenliği Bölümünde öğrenim gören öğrencilerin İngilizce konuşma yetkinliğini kazanmaya yönelik özerk öğrenme sürecine ilişsin görüşlerini ortaya koymaktadır. Öğrencilerin özerk öğrenme etkinliklerini ve İngilizce öğreniminde konuşma becerilerini etkileyen kaynakları ortaya çıkarmayı amaçlayan bu çalışma nitel araştırma yöntemiyle gerçekleştirilmiş olup, betimsel tarama modelindedir. Araştırmada veri toplama aracı olarak görüşme yöntemi kullanılmıştır. Öğrencilerin dil öğrenme süreci hakkındaki görüşlerini, İngilizce konuşma becerilerini geliştirmek için bireysel olarak yaptıkları etkinlikleri, konuşma becerilerini etkileyen kaynakları ve İngilizce konuşma becerilerini geliştirmek isteyen öğrencilere yönelik önerilerini ortaya çıkarmak için yarı yapılandırılmış görüşme formu hazırlanmış ve uygulanmıştır. Nitel veriler betimsel analiz yolu ile incelenmiş ve oluşturulan çerçeveye göre elde edilen veriler gerektiğinde doğrudan alıntılarla desteklenerek yorumlanmıştır. Dil öğrenme sürecinde öğrencilerin İngilizce konuşma yeterliliğini kazanmadaki özerk öğrenme etkinlikleri olarak yabancı arkadaşlıklar edinme, yabancı filimler izleme ve yabancı müzik dinleme, video oyunları oynama, drama kursu ve çevresel koşullar olduğu bulgularla ortaya çıkmıştır.

Anahtar sözcükler: özerklik; özerk öğrenme; İngilizce konuşma yeterliliği

\section{AUTHOR BIODATA}

Esmira Mehdiyev is an assistant professor in English Language Teaching at Sivas Cumhuriyet University, Turkey. She received her Ph.D. degree at Institute of Linguistics named after Nasimi, Azerbaijan National Academy of Sciences. Her field of study is linguistics, language acquisition, foreign language teaching, and teacher education. 